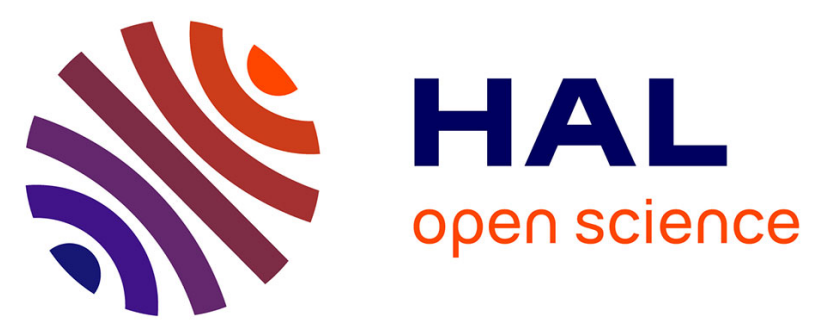

\title{
Bayesian modelling of an absolute chronology for Egypt's 18th Dynasty by astrophysical and radiocarbon methods
}

\author{
Anita Quiles, E. Aubourg, B. Berthier, E. Delqué-Kolic, G. Pierrat-Bonnefois,, \\ M. W. Dee, G. Audreu-Lanoë,, C. Bronk Ramsey, C. Moreau
}

\section{To cite this version:}

Anita Quiles, E. Aubourg, B. Berthier, E. Delqué-Kolic, G. Pierrat-Bonnefois,, et al.. Bayesian modelling of an absolute chronology for Egypt's 18th Dynasty by astrophysical and radiocarbon methods. Journal of Archaeological Science, 2012, 40 (2013), pp.423-432. 10.1016/j.jas.2012.05.026 . in2p300742997

\section{HAL Id: in2p3-00742997 \\ https://hal.in2p3.fr/in2p3-00742997}

Submitted on 17 Oct 2012

HAL is a multi-disciplinary open access archive for the deposit and dissemination of scientific research documents, whether they are published or not. The documents may come from teaching and research institutions in France or abroad, or from public or private research centers.
L'archive ouverte pluridisciplinaire HAL, est destinée au dépôt et à la diffusion de documents scientifiques de niveau recherche, publiés ou non, émanant des établissements d'enseignement et de recherche français ou étrangers, des laboratoires publics ou privés. 


\title{
Bayesian modelling of an absolute chronology for Egypt's $18^{\text {th }}$ Dynasty by astrophysical and radiocarbon methods
}

\author{
A. Quiles ${ }^{a b^{*}}$, E. Aubourgc ${ }^{c}$ B. Berthier ${ }^{d}$, E. Delque-Kolic ${ }^{a}$, G. Pierrat-Bonnefois ${ }^{\mathrm{e}}$, M. W. Dee ${ }^{\mathrm{f}}$, G. Andreu- \\ Lanoëe $^{\mathrm{e}}$ C. Bronk Ramsey ${ }^{\mathrm{f}}$ C. Moreau ${ }^{\mathrm{a}}$ \\ a : Laboratoire de Mesure du Carbone 14 (CEA/CNRS/IRNS/IRD/MCC), CEA-Saclay, Bât 450, P4E 91191 Gif- \\ sur-Yvette Cedex, France \\ b : Université Paris Diderot, Sorbonne Paris Cité, 5 rue Thomas Mann, 75013 Paris, France \\ c : APC, Université Paris Diderot, CNRS/IN2P3, CEA/Irfu, Obs de Paris, Sorbonne Paris Cité, France \\ d: Institut de Physique Nucléaire d'Orsay (IN2P3-Université Paris Sud), 15 rue Georges Clémenceau, Bâtiment \\ 100, 91406 Orsay Cedex, Paris, France
}

\begin{abstract}
e : Département des antiquités égyptiennes du Louvre, Musée du Louvre 75058 Paris Cedex 01, France
f : Research Laboratory for Archaeology and the History of Art, Dyson Perrins Building, South Parks Road, Oxford, OX1 3QY, United Kingdom
\end{abstract}

*Corresponding author: anita.quiles@gmail.com

\section{Introduction}

From the beginning of modern Egyptology, the establishment of an absolute chronology for Ancient Egypt has been an ambition which has concentrated the minds of many scholars. Pioneers in the field constructed a relative chronology by re-studying Graeco-Roman sources and deciphering ancient Egyptian writing. Firstly, Herodotus's writings were re-translated providing the first pieces of information that led up to Manethon's epitomes, which proposed lists of kings and the lengths of their reigns. These documents led to the first organization of Egyptian time into 31 groups of kings, called dynasties. The second major advance came with the studies of Champollion and his followers, who succeeded in understanding how to read hieroglyphs, the writing of the ancient Egyptians. Thus, Egyptian sources became comprehensible and archaeology brought to light documents of great interest which contained lists of the kings who reigned in Egypt. The Palermo Stone, the Abydos reliefs and the Turin Canon proposed lists of the kings and their order of succession. All these documents, to which are added a host of archaeological discoveries, have permitted Egyptologists to build a relative chronology for ancient Egypt. Henceforth, the 3000 years of dynastic history were divided into six periods. The three "stable" periods, called the Old, Middle and New Kingdoms are separated by three periods when the Egyptian state was divided between the North and the South: the First, Second and Third Intermediate Periods. Following the Manethonian tradition, these periods are organized into dynasties: the Old Kingdom (OK) consists of the Dynasties (Dyns) 3-6, the Middle Kingdom (MK) of the Dyns 11-13 and the New Kingdom (NK) of the Dyns.18-20. Dyns.1-2 precede the Old Kingdom and thus form the so-called Early Dynastic Period (EDP); Dyns.7-10 make up the First Intermediate Period (FIP); Dyns. 13-17, the Second Intermediate Period (SIP); Dyns.21-25, the Third Intermediate Period (TIP). Lastly, the Third Intermediate Period is followed by the Late Period (Dyn.26) and the Graeco-Roman Period. This study will focus on the $18^{\text {th }}$ Dynasty of the NK, for which museum held sufficient material to permit the development of relevant Bayesian models. 
In Ancient Egypt, the notion of time was totally different to ours and relied on deep religious principles. Civil time was organized by a calendar based on agricultural seasons, divided into different units of time: a year contained three seasons (Akhet, Peret and Shemu) of four months and each month lasted thirty days. Five feast-days, called epagomenol days, were added at the end of the year. There was no larger unit of time than the year. Historical time was just expressed in reference to the ruling king: as examples, the construction of the Akhmenu of Karnak was described as being built in year 24 of Thutmoses III, and the battle of Qadech took place in year 5 of the reign of Ramses II.

Such an organization of time means that we would need to know the exact succession of all the kings and their precise length of reign, to re-establish an absolute chronology for Ancient Egypt. Unfortunately, our state of historical and archaeological knowledge does not permit the reconstruction of such a long period of history and Egyptologists used to date an event by citing the relevant Kingdom or Intermediate Period and the Dynasty and possibly the king under which the event occurred.

In the present study, we propose a new approach based on a statistical method, called Bayesian modelling, to establish an absolute chronology for Egypt's $18^{\text {th }}$ Dynasty. In this model, which includes different absolute astrophysical and physical methods, radiocarbon dates give the base-information, which is then constrained by results deduced from Sothic and Lunar methods calculated with a Bayesian approach, as well as Egyptian textual sources, and incorporated as a priori to the radiocarbon information.

\section{Materials and Methods}

\subsection{Bayesian modelling}

A probabilistic approach, called Bayesian statistics, allows us to define observations taking into account our global knowledge on a studied object/event. Bayesian modelling is based on subjective hypotheses that represent the state of the established knowledge when the dating is performed. Such an approach highlights the combination of two systems of time: the first is relative time (represented by the archaeological evidence) and incorporated as a priori to a second time, which is absolute time, represented by measurement and called the likelihood. The age deduced by combining archaeological and dating information, is the a posteriori law, and this distribution has to be accepted or rejected depending on particular criteria that we have to define in advance. Such an approach seems to be particularly appropriate for dating archaeological objects/events since contextual as well as stratigraphic information is usually established before measurement.

In particular, radiocarbon dates are rarely the only information we have on analyzed objects. The archaeological context in which they were found/conserved as well as the correlations between objects (inbuilt age, contemporaneity, position of one object to another, etc...) give extra information. This may improve the precision of the age distributions deduced by radiocarbon dating, by constraining the radiocarbon densities by using archaeological evidence.

So, this Bayesian approach was firstly performed on Lunar dating, by writing our own $\mathrm{C}++$ programme. Then, we modelled radiocarbon measurements using OxCal 4.1, and we used priors (combine, phase, sequence, gap, interval, boundary, Delta_R), agreement and convergence factors following the terminology proposed in (Bronk Ramsey, 2009).

\subsection{Sothic Dating}


Sothic Dating was the first method used by Egyptologists to establish the backbone of an absolute chronology for Ancient Egypt (Borchardt, 1899; Neugebauer, 1929; Parker, 1977; Krauss, 1985). This method is based on the observation of the star Sirius/Sothis, called Sopdet by the ancient Egyptians. Sopdet was an Egyptian goddess who had been known since the first Egyptian dynasty, and who was identified with the star Sothis, the brightest star in the night sky. Each year, Sothis disappears from the sky of an observer in Egypt and reappears about seventy days later. This phenomenon is called a Sothic rising. By pure coincidence, the time of reappearance of this star in the Egyptian sky corresponded with the time of the annual Nile flood. As a result, Sopdet was considered the goddess of fertility. This coincidence led Egyptians to base their calendar on the Sothic rising. When their calendar was created, the first day of the first month of the year was a day close to the Nile flood, and was also the day of the reappearance of Sothis. However, the Egyptian year lasted 365 days whereas the Sothic year was of 365 days plus one quarter. Thus, a gap of one day per four years had been created between this Egyptian civil year and the Sothic year. It meant that four years after the creation of the calendar, the Sothic rising occurred the second day of the year, eight years after, the third day etc.... So, a Sothic cycle is the time which separates two Sothic risings which have occurred the same day in the civil Egyptian calendar. It lasted 1460 Julian years $(365 * 4=1460)$, which means 1461 Egyptian years. In reality, this value is not totally exact: the Sothic cycle is not fixed because of the own movement of the star and the length of Sothic year evolves in time.

Egyptians were aware of this offset between their civil calendar and the Sothic cycle but never modified it. Thus, they sometimes engraved the correspondence between the heliacal rising of Sothis's star and the date on which it occurred (king, year, month and day). These "Sothic equations" are of the utmost importance because an absolute chronological date for the year of the ruling king can be deduced from them. Sothic documents are attested, in particular a Sothic equation was found on a stone excavated at Elephantine Island, near Aswan. This block refers to an offerings' calendar, and in this document, presently exhibited at the Louvre Museum (E 3910), it is written: "3 $3^{\text {th }}$ month of the season Shemu, day 28, day of the feast of the coming of Sopdet, ..." which means that a Sothic rising occurred the $28^{\text {th }}$ day of the third month of the season Shemu (Shemu.III.28), under an unknown king. A Roman writer called Censorinus wrote in De Die Natali (Censorinus) that the 19 July 138 C.E was the first day of this Egyptian civil year. This association gave us the first piece of information to evaluate absolute dates on which Sothic risings occurred. Then, we used a method, based on the arcus visionis estimation. It is the smallest angle difference between the sun and the rising of a star that is necessary for the celestial object to be just visible at its rising by a person on the earth. Our method estimates the absolute date on which the Sothic rising occurred, according to Julian years (Aubourg, 2000).

\subsection{Lunar Dating}

In parallel with the civil calendar, a lunar calendar was used in ancient Egypt, especially in temples (Parker, 1950 ; Depuydt, 1997). It was based on 12 months of 29 or 30 days, and the first day of the month was the first day of the moon's invisibility. Thus, the length of the month was determined by observation of the moon on the $29^{\text {th }}$ day: if the moon was again visible, the month lasted one more day and the new one begun the day after the following day, but if it was invisible, this following day was considered the first day of the new month.

Some lunar equations are attested in the texts, in particular during the reign of Thutmoses III: they consist in associating one phase of the moon with a date in the Egyptian civil calendar. Now, days and 
hours of new moons around the reign of Thutmoses III have been tabulated thank to the JPLHORIZONS software (JPL Horizons) developed by the NASA. With a Bayesian approach, we have determined the more probable dates of observation of new moons attested in Egyptian texts, by synchronizing these lunar equations with the previous Sothic method.

\subsection{Radiocarbon Dating}

At LMC14 (CEA Saclay, France), two sets of radiocarbon analyzes were carried out on short-life objects conserved at the Louvre museum and archaeologically attributed to a specific reign or short period of the $18^{\text {th }}$ Egyptian Dynasty. Care was taken to sample objects without preservatives. Samples were treated using Saclay's routine pretreatment process for organic material (acid -base-acid procedure consisting of $\mathrm{HCl}\left(0.5 \mathrm{~N}, 1\right.$ hour, $\left.80^{\circ} \mathrm{C}\right), \mathrm{NaOH}\left(0.1 \mathrm{~N}, 1\right.$ hour, $\left.80^{\circ} \mathrm{C}\right)$ and $\mathrm{HCl}(0.5 \mathrm{~N}, 1$ hour, $\left.80^{\circ} \mathrm{C}\right)$ ). They were then dried and combusted at $900^{\circ} \mathrm{C}$ with $\mathrm{CuO}$ and silver wire. $\mathrm{CO}_{2}$ produced was collected cryogenically before being reduced to graphite with $\mathrm{H}_{2}$ and $\mathrm{Fe}$ powder at $600^{\circ} \mathrm{C}$. Measurements were performed with the AMS method at the ARTEMIS Facility. Calibration and Bayesian modelling were realized using the OxCal4.1 program (Bronk Ramsey, 1995), using IntCal09 curve (Reimer et al, 2009). Radiocarbon results are used to be given with one standard deviation and calibrated ages, with two sigmas deviation. In the modelling, an offset of $19 \pm 5$ years was added to each radiocarbon date, following the study of the Oxford Laboratory on the reservoir offset in Egypt (Dee et al, 2010) and using the Delta_R function (Bronk Ramsey, 2009).

\subsubsection{Sennefer's tomb at Deir el-Medineh}

Bouquets of flowers found in Sennefer's tomb at Deir el-Medineh by the French Egyptologist Bernard Bruyère (Bruyère, 1929) (Figure 1), were radiocarbon dated. 47 samples were analyzed; we sampled different short-life plants (leaves, twigs, etc..) to ensure the consistency of the dates. They came from seven different bouquets. The archaeological material found inside the tomb shows three burial phases. They occurred between the beginning of the reign of Tutankhamun and the beginning of the reign of Horemheb, which means a period of about 15 years (Bruyère, 1929). In his excavation reports, Bernard Bruyère states that he found all the bouquets at the entrance of the tomb, which means that such material precisely dates the same archaeological event: one of the three phases of burial.

\subsubsection{Basketries from Deir el-Medineh}

Basketries from the eastern cemetery of Deir el-Medineh (Figure 2) are held at the Louvre Museum. They were found by Bernard Bruyère in the excavations he led between 1928-39, then offered to the Louvre Museum as in recognition of the museum's support for the excavation. The cemetery was used by a relatively modest, almost exclusively female, population. It can be inferred by the study of the archaeological material found inside these tombs (ceramic, scarabs...) that burials in this cemetery occurred at the beginning of the $18^{\text {th }}$ Dynasty. In particular, scarabs with the names of queen Ahmes Nefertari, queen Hatshepsut, and king Thutmoses III are attested (Bruyère, 1937; Pierrat-Bonnefois, 2003). 19 basketries were analyzed by 78 measurements performed on short-life samples of palm, alfa, grapes and seeds, 53 by LMC14 laboratory and 25 by ORAU laboratory. Some of these results have already been incorporated in the 'Radiocarbon-based chronology for dynastic Egypt' proposed by the Oxford laboratory (Bronk Ramsey et al, 2010).

\section{Results}

\subsection{Sothic Dating}


The Elephantine Calendar refers a Sothic rising on Shemu III.28 at Elephantine Island, which corresponded to the $328^{\text {th }}$ Egyptian civil day. To elaborate, Figure. 3 shows that around 1450 B.C.E, the Sothic rising occurred at Elephantine at about the $10.5 \pm 0.75 / 0.5$ Julian July. This $10.5 \pm 0.75 / 0.5$ Julian July has to be the $328^{\text {th }}$ or the $327^{\text {th }}$ day of the civil Egyptian calendar, since we have to consider an uncertainty of one day between the observation day and the effective day of the Sothic rising. From Censorinus text, we know that 19 Julian July 138 EC corresponded to Akhet.I.1, from what we calculated that the 11/10 Julian June 138 EC corresponded to Shemu.III.28/27. By subtraction, we deduced that Shemu.III.28/27 corresponded to the $10.5 \pm 0.75 / 0.5$ Julian July between 1439 and 1448 $\mathrm{BCE}$, which enable to conclude that this heliacal rising of Sothis took place in $1443.5 \pm 4.5$ B.C.E (Figure 3). Unfortunately, the year of the ruling king on which this observation was made isn't mentioned, but it may firstly be shown that this block was engraved during the reign of Thutmoses III (Bommas, 2000), which lasted 53 years (Hornung, 2006). Besides, the study of the archaeological context on which the Elephantine calendar was found leads us to the conclusion that the wall on which it was located could not have been engraved before the year 33 of this king. Thus, we deduced that $1443.5 \pm 4.5$ B.C.E must be between the year 33 and 54 of Thutmoses III (Quiles, 2010).

In addition, for Egypt's $18^{\text {th }}$ Dynasty, successions of kings and lengths of their reigns are relatively well-known, as summarized in TAB. 3. Combining the derived equation with the known lengths of reigns, termini were calculated for each reign of this dynasty. Thus, we deduced that $1568.5 \pm 4.5$ B.C.E. and $1285.5 \pm 4.5$ B.C.E. were respectively termini post and ante quos for the beginning and the end of the $18^{\text {th }}$ Dynasty. These termini were obtained without preferring one Egyptologist's estimations to another.

\subsection{Lunar Dating}

Thutmoses III relates two lunar equations in his Annals. The first one is attested as the day of the beginning of the Megiddo Battle. He explains: "Year 23, It month of Shemu, day 21, day of the battle of Megiddo, day of the feast of the new moon" (Urk.IV.657.1). The following year, the king inaugurated the Akhmenu, a festival hall he built in the Karnak complex. He said: "My majesty orders to prepare the ceremony of foundation to come the day of the feast of the new moon, for the act of foundation of this monument, in the year 24, $2^{\text {nd }}$ month of the season Peret, last day" (Urk.IV, 836.2). Knowing the accession date of Thutmoses III in the Egyptian calendar (Shemu.I.4, (Urk.IV.180, 15-16)) and being aware that during the New Kingdom, the first year of a king always lasted 365 days, we deduced that these two dates are separated by 649 days. Besides, thanks to Sothic dating we established years 23 and 24 of Thutmoses III were between 1480 and 1448 B.C.E. And by calculating the correspondent day of these two celebrations in the Julian calendar, we deduced that these new moons occurred between $1^{\text {st }}$ and $20^{\text {th }}$ May for year 23, and between 8 and 27 February for year 24 (Quiles, 2010). With JP1-Horizons software, the new moons of February and May between 1480 and 1448 B.C.E. were tabulated. Texts do not however specify whether the Egyptians observed the moon in the morning or in the evening. This information is of prime interest because the day of observation of a new moon could have been different from the actual day (for instance, if Egyptians used to observe the new moon in the morning, a new moon which was sighted at about $9 \mathrm{pm}$ was observed on day $\mathrm{D}+1$ rather than day $\mathrm{D}$.).

For this reason, we have written two models of calculation in $\mathrm{C}++$ language, using a Bayesian approach, to determine the more probable day of observation. As likelihood, we have taken a Gaussian law of distribution, in view of the probability of being able to observe the new moon once you know it 
has occurred. Two a priori laws were tested, according to an observation in the morning, or in the evening. These a priori laws were defined as Heaviside functions except around the boundaries where the probability of observation was fixed with a Gaussian law (sunrise and sunset). The difficulty was to set boundaries of the hours up to which observation was possible. They were set in reference to the hours of sunrise and sunset (consequently, the boundaries are not the same for the new moon's observation in May or in February). As a result, the a posteriori law answered the question: "knowing the effective hour of the new moon, and postulating a type of observation (morning or evening), what is the probability the observation was done on day $D$ or day $D+1$ ?"

After having tabulated the more probable days for observation of the two new moons (February and May) between 1480 and 1448 B.C.E., we checked the ones separated by 649 days. The sum of results of the two models enables us to propose a set of 12 years that are possible as year 1 for the reign of Thutmoses III. These are summarized in Figure 4. (Quiles, 2010)

\subsection{Radiocarbon dating}

\subsubsection{Sennefer's tomb}

In the 47 analyses carried out on bouquets from Sennefer's tomb (TAB.1), five outliers were identified. At first we considered samples coming from the same bouquet as dating the same archaeological object, so having the same age. These ages were combined using $R$ _Combine function in OxCal 4.1 (Bronk Ramsey, 1995) so as to get one age per bouquet, and they were then constrained by termini post and ante quos for, respectively, the accession date of Tutankamun and Horemheb, deduced from Sothic dating (1356.5 \pm 4.5 B.C.E. and $1312.5 \pm 4.5$ B.C.E.). The seven ages obtained are contemporaries and spread out over a period from 1420 to 1260 calBC (Figure 5).

Because the seven bouquets were found one on top of the other at the entrance of the tomb, we can proceed to consider that all the bouquets precisely date to the same archaeological event. The combination of the seven probabilities, constrained by the same termini, leads to the proposition that the bouquets were put out in Sennefer's tomb between 1358 and 1312 calBC (Figure 5).

\subsubsection{Basketries from Deir el-Medineh}

The 19 basketries from the eastern cemetery of Deir el-Medineh were analyzed by one to nine measures (TAB.2) and 10 outliers were identified. The validated dates have been combined to get one probability density for the age of each object. 14 are in the reign of Thutmoses III whereas four basketries (E 14487, E 14479, E 14617 and E 16397) could be older (around the beginning of the New Kingdom). For specifying the period of activity of this cemetery, we have tried to identify the original tomb of some of the basketries. The study done by Y. Gourlay and the description of the tomb detailed by $\mathrm{B}$. Bruyère permit the finding of the original tomb of nine objects, but it was not possible to proceed for the last ten (Gourlay, 1981 ; Bruyère, 1937). As an example, we observe that four basketries come from tomb 1382, in which three sarcophagi were found (Bruyère, 1937). These three burials did not occur at the same time, so we cannot say that the four basketries have the same age. Moreover, we cannot consider that the basketries precisely date the tombs or a burial phase, because a person could have been buried with a basket that was 10/20 years older. So an archaeological uncertainty of one to two generations has to be applied between the age of the basketries and the ages of burial phases in these tombs.

\section{Egypt's $18^{\text {th }}$ Dynasty model}


The comparison of dates deduced from Sennefer's tomb and the ones from basketries, synchronized with Sothic and Lunar methods, allow an absolute chronology for Egypt's $18^{\text {th }}$ Dynasty to be modelled with a Bayesian approach.

\subsection{Accession date for Tutankhamun}

The association of the ages of the Sennefer's bouquets with a historical period is more precise than for the basketries, as the former are associated with the interval from the beginning of the reign of Tutankhamun until the beginning of the reign of Horemheb, which is a period of 15 years, whereas an uncertainty of one to two generations surround basketries. That is why we chose to favor Sennefer's probability density for the construction of our chronology. However, to establish an absolute chronology we need a starting point associated with a precise historical event, like the accession date for Tutankhamun. So, we multiplied the combined density we got for "one phase of burial in Sennefer's tomb" by a rectangular function from 1 to 15 years, to simulate a distribution of age for the beginning of the reign of Tutankhamun. This age was then constrained by the termini post and ante quos for the beginning of this reign, deduced from the Sothic method. We obtained the result that Tutankhamun became king of Egypt between 1359 and 1319 calBC $(2 \sigma)$. This age takes into account archaeological as well as physical uncertainties (Figure.6).

\subsection{Accession date for Thutmoses III}

The information from Sennefer's tomb is more precise than the attribution of the basketries to Thutmoses III. The length between the beginning of the reign of the latter and Tutankhamun is relatively well known (between 140 to 149 years, TAB.3). That is why, in the same way, we simulated an age for the beginning of the reign of Thutmoses III, from the age of Tutankhamun (1499-1463

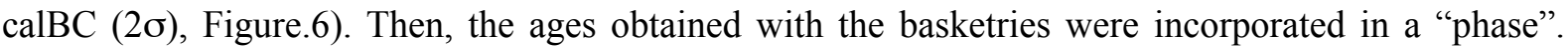
Additionally, the years calculated by Lunar dating as possible estimates for year 1 of the reign of Thutmoses III were added in another "phase". We defined these lunar dates by Normal distributed errors of one year. These two phases and the simulated date were integrated in another bigger phase, so as to constraint the simulated age by the two first phases. Finally, the density we get for the accession date of Thutmoses III was constrained by termini post and ante quos for the beginning of this reign, deduced by the Sothic method. The youngest lunar date was rejected by calculation (agreement factor was too low) and with a set of 11 lunar dates, the model is accepted with an agreement factor of 81. It suggests we consider that the reign of Thutmoses III began between 1499 and 1471 calBC $(2 \sigma)$.

The reign of Thuthmose III has been the central focus of several chronological analyses on the New Kingdom, using astronomical as well as historical approaches (Krauss 1985; Leitz, 1989; Grimal, 1988; Beckerath, 1994; Shaw, 2000; Hornung et al., 2006). The aim of this paper is to provide a new account, using only the most reliable archaeological information in combination with the latest chronometric techniques.

\subsection{Accession Dates for each king of Egypt's $18^{\text {th }}$ Dynasty}

Consequently, we have obtained two dates for two different reigns of the $18^{\text {th }}$ Dynasty and we have termini post and ante quos for the beginning and the end of this period, thanks to Sothic dating. That is, we have four corner points. For this period, the succession of the kings and the length of their reigns are well attested in history and archaeology. The majority of them are known with an 
uncertainty of about one to two years, but three are not as well-established and their uncertainty is of about 10 years. For the first group, we chose to define a probability distribution for the length of the reign by a rectangular function. This affords equal probability to each year of the function. Even if this kind of distribution law is restrictive for the calculation of the model, it represents our state of knowledge. On the other hand, the length of Thutmoses Ist, Thutmoses II and Horemheb's reigns are not as well established. For instance, some Egyptologists affirm that Horemheb's reign lasted 13 years whereas others claim it reached 27 years. That is why we chose to define this probability density using the Before and After OxCal functions (Bronk Ramsey, 2009). Because the reign lasted at last 13 years, we used the restrictive After(13) function. Then, because it could have lasted more that 13, and until 27 years, we combined the former with a Before $(27+\mathrm{T}(5))$ function. Such a probability density makes the distribution more flexible. Lengths of Thutmoses ${ }^{\text {st }}$ and Thutmoses II's reigns were defined using the same functions.

As a result, we have simulated an interval of age per king by the multiplication of these relationships on the length of the reigns, to one of the two simulated radiocarbon's densities we got for Thutmoses III and Tutankhamun (Figure 7 and TAB. 3).

\subsection{Implications on our model}

Our model calculated an age distribution for the accession date of each king of Egypt's $18^{\text {th }}$ Dynasty, which synchronizes radiocarbon, Sothic, lunar, historical and archaeological information. Intervals are about 32 (Thutmoses III) to 45 (Horemheb) years with 95\% probability (TAB. 3). They are shorter for the beginning of the dynasty which means the terminus post quem we calculated is relatively precise. For the end of the dynasty, the model is more flexible because intervals are larger. This can be explained by the fact the terminus ante quem we use is lower. It was calculated thanks to Sothic method, combined with historical information on the lengths of reigns. It means we have summed the maximum lengths for each reign after Thutmoses III, and taken as a starting point the first possible year possible for estimating the year of observation of the Sothic rising engraved on the Elephantine Calendar. Anyway, given our state of knowledge, we could not calculate a higher terminus ante quem without preferring one Egyptologist's interpretation over another. But, that could show that a couple of reigns were shorter that what we used, in particular for reigns for which the length is not well established. Another explanation would be the Sothic rising's observation could have occurred closer to the end of Thutmoses III's reign, rather than around year 33. But, this can not be definitively established.

This model may be further improved if we get information on another constraint (like a more precise knowledge on the length of a reign, another astrophysical observation, etc...). But, at present, modelled intervals are strongly correlated, which means new information on just one reign will significantly modify each interval. Getting more dates for different reigns that Thutmoses III and Tutankhamun seems to be the best solution to get an "asymptotic model". The more constraints we establish, the less intervals will vary.

\section{Conclusions}

Radiocarbon dating is a physical method which can be used to determine probability densities for the age of archaeological events. Thanks to historical and archaeological evidence, the succession of kings and lengths of their reigns for the $18^{\text {th }}$ Egyptian Dynasty are relatively well-established. Besides, we have astrophysical equations attested in Egyptians texts which allow us to calculate anchor points in 
Egyptian chronology. The first one is Sothic dating and in this paper we have shown, firstly, that these equations allow us to minimize uncertainties by using arcus visionis method. As a result, we achieved a relatively precise anchor point for the reign of Thutmoses III. Combined with our knowledge on the succession of the kings and the lengths of their reigns, we were able to fix termini for each of the reigns of the $18^{\text {th }}$ Dynasty. Lunar dates were then a second source of information and we developed a Bayesian model which calculates the more probable days of observations of new moons, given the type of observation (morning or evening). By incorporating the two lunar equations attested in the Annals of Thutmoses III, we deduced a set of 12 years as possible estimates for the accession date of this king. Then, two radiocarbon studies were carried out at LMC14 and ORAU on samples archaeologically attributed to a period Tutankhamun-Horemheb and Thutmoses III. The first leads to precisely dating one phase of burial in Sennefer's tomb, and from that result we simulate a date for the beginning of Tutankhamun, then for Thutmoses III. The second was constrained by densities we obtained on basketries from Deir el-Medineh, and by lunar dates. According to our knowledge on the length of each reign of the $18^{\text {th }}$ Dynasty, we finally determined a probability distribution for the length of each reign of this period, which allows the simulation of a period for the accession date of each king of this dynasty. These temporal probability densities incorporate Sothic, Lunar, radiocarbon, archaeological and historical information.

Our model was applied on a reliable Egyptian period and results we got are in perfect agreement with dates previously deduced by some Egyptologists from methods unused here. This allows us to conclude that such an approach should certainly be applied to older Egyptian periods, for which the textual sources are less extensive.

\section{Acknowledgements}

This project was realized in the framework of a Physics PhD led at the LMC14 lab (AQ), supervised by B. Berthier (BB), and funded by the University Paris Diderot, and a Master of Egyptology at the University Paris IV-Sorbonne (AQ), supervised by E. Aubourg (EA) and D. Valbelle to whom we are grateful. Radiocarbon measurements were mainly performed at the Laboratoire de Mesure du Carbone 14 (CEA Saclay, France), funded by the CEA, CNRS, Ministère de la Culture et de la Communication, IRSN and IRD (AQ, EDQ, CM). We are indebted to all the LMC14 team for its rigorous work and its involvement in this project. Oxford dates were realized at the Oxford Radiocarbon Accelerator Unit (University of Oxford) in the framework of the Egypt Chronology Project, funded by the Leverhulme Trust (MD, CBR). Archaeological samples analysed in this study are held at the Département des Antiquités égyptiennes from the Louvre Museum which generously authorized us to collect them (GPB, GAL). We are also grateful to Dominique Bavay and Nicolas Durand for their thorough comments during the writing of this paper.

\section{References}

- Aubourg, E., 2000, Sirius et le cycle sothiaque, BIFAO 100, 37-46.

- Beckerath, J. Van, 1994, Chronologie des ägyptischen Neuen Reiches. Gerstenberg Verlag, Hidlesheim.

- Bommas, M., 2000, Der Tempel des Chnum der 18. Dyn. Auf Elephantine, Inauguraldissertation zur Erlangung der Doktorwürde vorgelegt der Fakultät für Orientalistik und Altertumswissenschaft der Universität Heidelberg. 
- Borchardt, L, 1899, Der zweite papyrusfund von Kahun und die zeitlische festlegung des mittleren reiches der ägyptischen geschichte, Zeitschrift für Ägyptische Sprache und Altertumskunde (Z̈̈S) 37, 99.

- Bronk Ramsey, C., 1995, Radiocarbon Calibration and analysis of stratigraphy: the OxCal program Radiocarbon 37 (2), 425-430.

- Bronk Ramsey, C., 2009, Bayesian analysis of radiocarbon dates, Radiocarbon 51 (1), 337-360.

- Bronk Ramsey, C, Dee, M. W., Rowland, J. M., Higham, T. F. G., Harris, S. A., Brock, F. , Quiles, A., Wild, E. M., Marcus, E. S., Shortland, A. J., 2010, Radiocarbon-Based Chronology for Dynastic Egypt, Science 328, 1154-1557.

- Bruyère, B., 1929, Rapport sur les fouilles de Deir el-Medineh, La tombe de Sennefer.

- Bruyère, B., 1937, Les tombes du cimetière Est de Deir-el-Medineh, FIFAO XV.

- Censorinus, De Die Natali, (French Translation): J. Mangeart, Livre de Censorinus sur le Jour Natal, Paris, 1843.

- Dee, M.W., Brock, F., Harris, S.A, Bronk Ramsey, C., Shortland, A. J., Higham, T. F.G., Rowland, J. M., 2010, Investigating the likelihood of a reservoir offset in the radiocarbon record for ancient Egypt, JAS 37, 687-693.

- Depuydt, L. 1997, Civil calendar and Lunar calendar in Ancient Egypt, Orientalia Lovaniensia Analecta 77.

- Grimal, N., 1988, Histoire de l'Egypte ancienne, Fayard.

- Gourlay, Y., 1981, Les sparteries de Deir el-Medineh, XVIII-XX dynasties. Documents de fouilles de l'IFAO, Le Caire.

- Hornung, E., 2006, The New Kingdom, in Ancient Egyptian Chronology, Handbook of Oriental Studies, Brill, pp. 197-217.

- Hornung, E., Krauss, R., Warburton, D. A., 2006, Ancient Egyptian Chronology, Handbook of Oriental Studies, Brill.

- JPL Horizons, http://ssd.jpl.nasa.gov/?horizons.

- Krauss, R., 1985, Sothis- und Monddaten, Studies zur astronomischen und technischen Chronologie altägyptens, Hildesheimer Ägyptologische Studien 20, Hildesheim: Gerstenberg.

- Leitz, Ch., 1989, Studien zur ägyptischen Astronomie. Ägyptologische Abhandlungen 49, Wiesbaden: Harrasowitz.

- Neugebauer O., 1929, Astronomische Chronologie, Berlin.

- Parker, R. 1950, The calendars of Ancient Egypt. Studies in ancient oriental civilization $\mathrm{n}^{\circ} 26$, University of Chicago Press.

- Parker, R. 1977, The Sothic date of the twelfth and eighteenth dynasties. In Studies in honor of G. R. Hughes.

- Pierrat-Bonnefois, G., 2003, Cimetière est du village ou cimetière à l'est de Deir el-Medineh., In Deir el Medineh et la Vallée des rois, (ed) G. Andreu-Lanoë, Editions Khéops, pp. 49-65.

- Quiles, A., 2010, Le règne de Thoutmosis III, mise en perspective des données participant à l'établissement d'une chronologie absolue et restitution du Calendrier d'Eléphantine dans son contexte d'origine. Master in Egyptology, University Paris IV-Sorbonne.

- Reimer et al, 2009, Intcal09 and Marine09 radiocarbon age calibration curves, 0-50,000 years cal BP., Radiocarbon 51(4), 1111-1150.

- Shaw I., 2000, Ed., The Oxford History of Ancient Egypt, Oxford University press, Oxford.

- Urkunden des ägyptischen Altertums. 


\section{Figure Captions:}

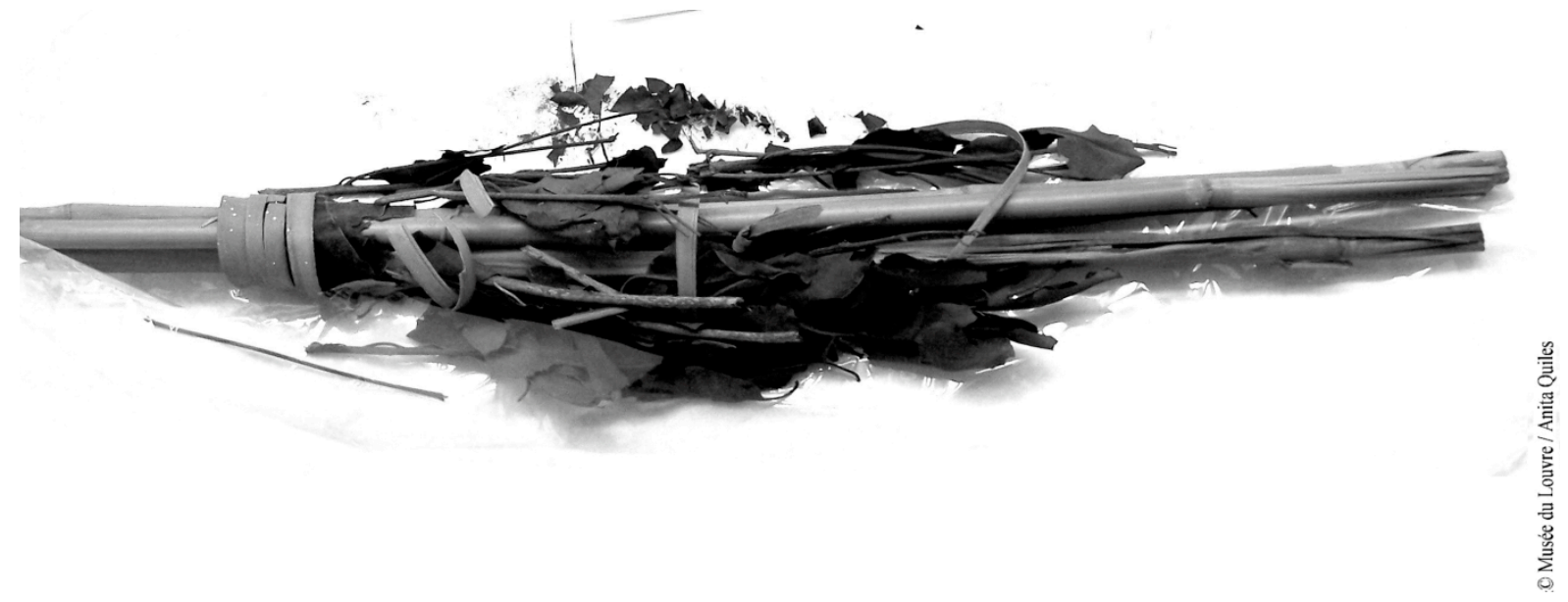

Figure 1: one of the seven bouquets from Sennefer's tomb (E 14000), held at the Louvre Museum

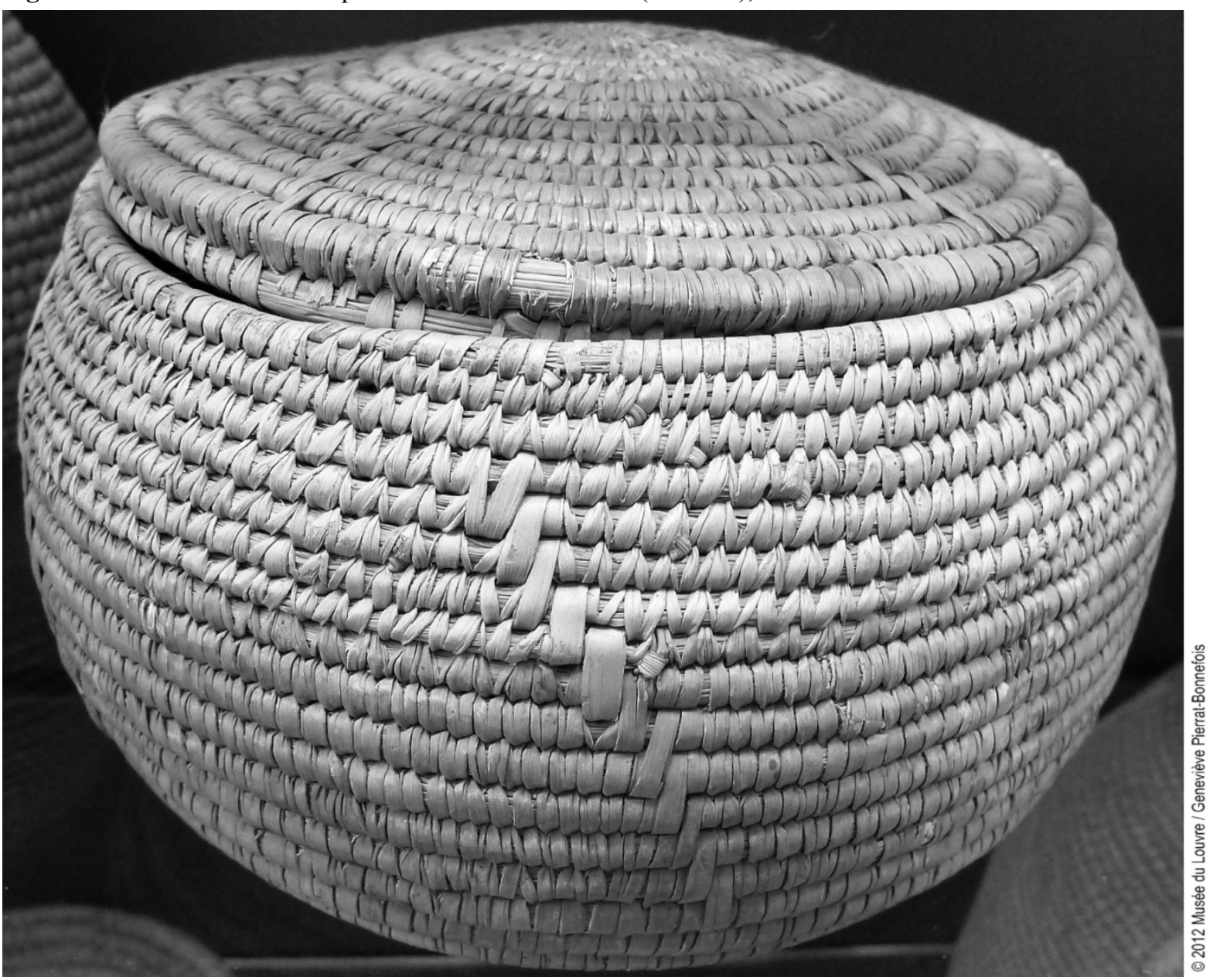

Figure 2: Basketry E 16391, held at the Louvre Museum. Two ${ }^{14} \mathrm{C}$ dates were performed on palm and halfa samples and the deduced combined density shows that this object was fabricated during the reign of Thutmoses III. 


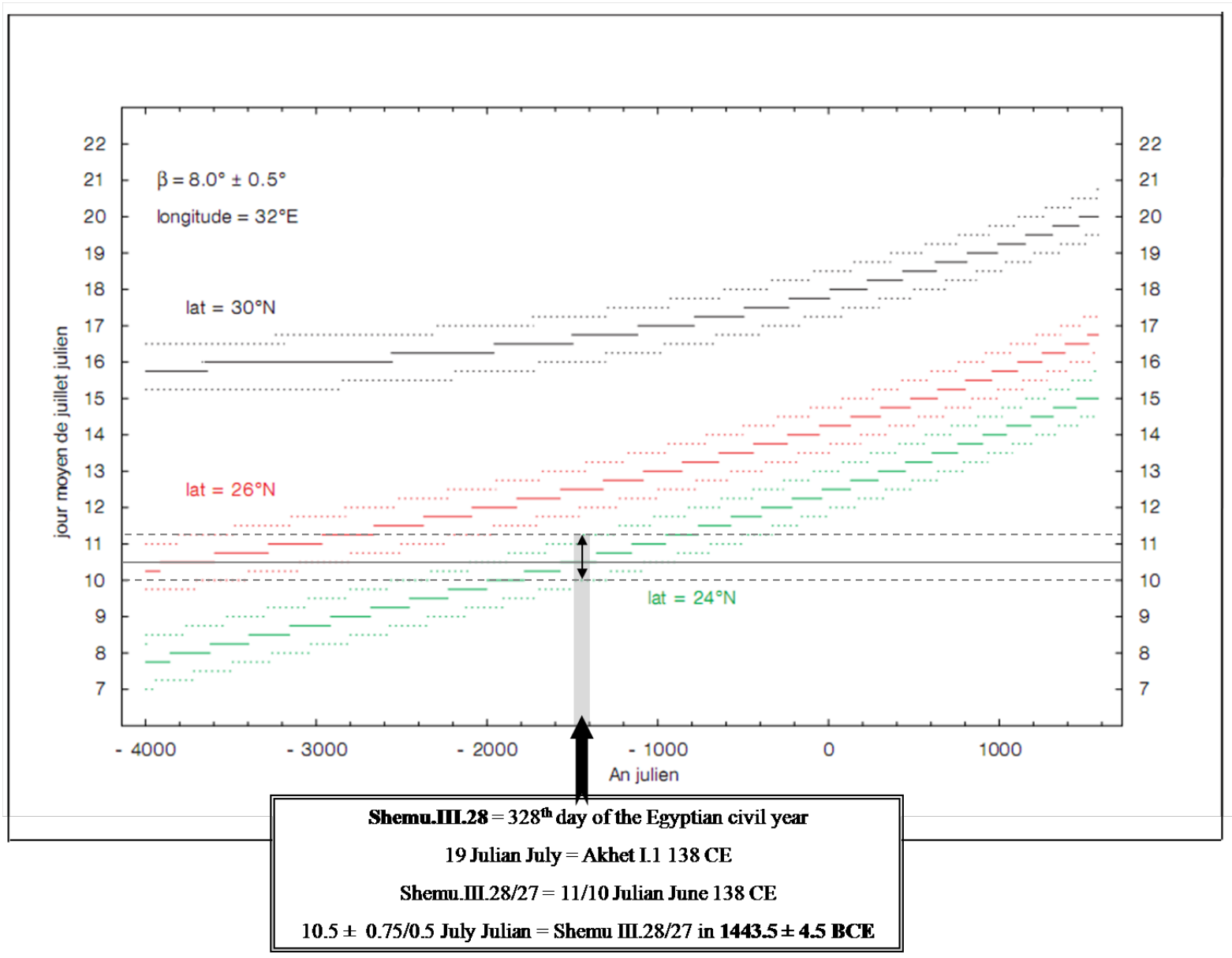

Figure 3: Determination of the Sothic rising's day in Julian July, from (Aubourg, 2000, p. 46). We can observe on this graphic that around 1450 B.C.E, Sothic rising occurred at $24^{\circ} \mathrm{N}$, at $10.5 \pm 0.75 / 0.5$ Julian July. Because the 19 Julian July 138 EC corresponded to Akhet.I.1, we deduced that $10.5 \pm 0.75 / 0.5$ corresponded to Shemu.II. 28/27 from 1448 to 1339 B.C.E.

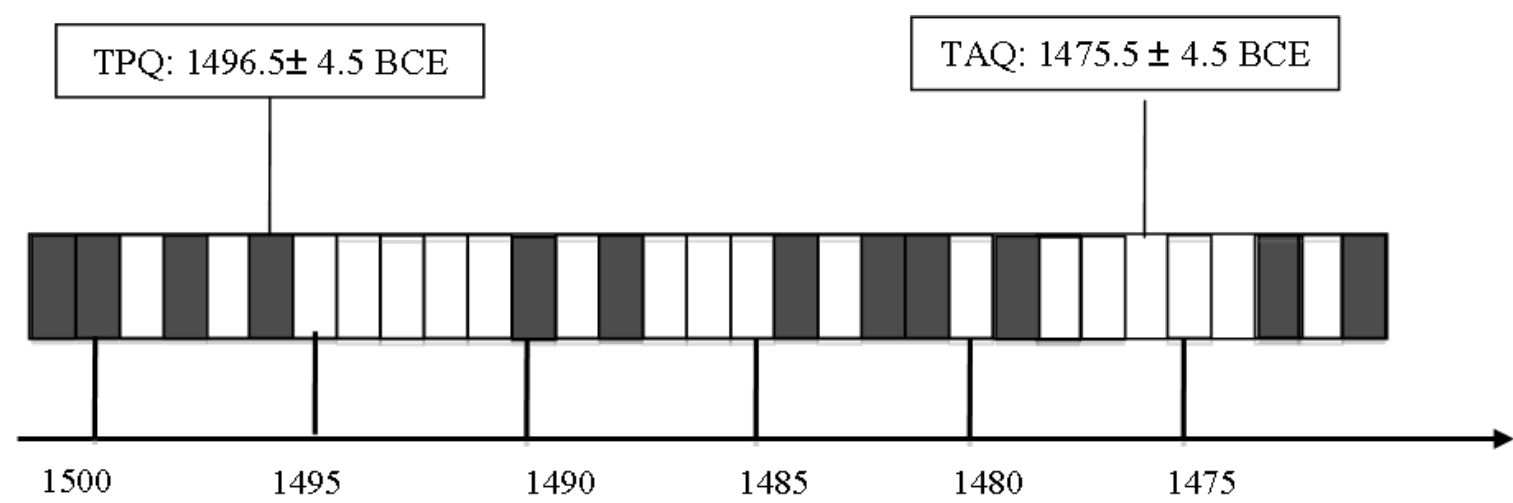

\section{Estimates for the accession date of Thutmoses III}

Figure 4: Results of Bayesian modelling of lunar dates attested in Thutmoses III Annals. A set of 12 estimates are given for the accession date of this king (in dark). 


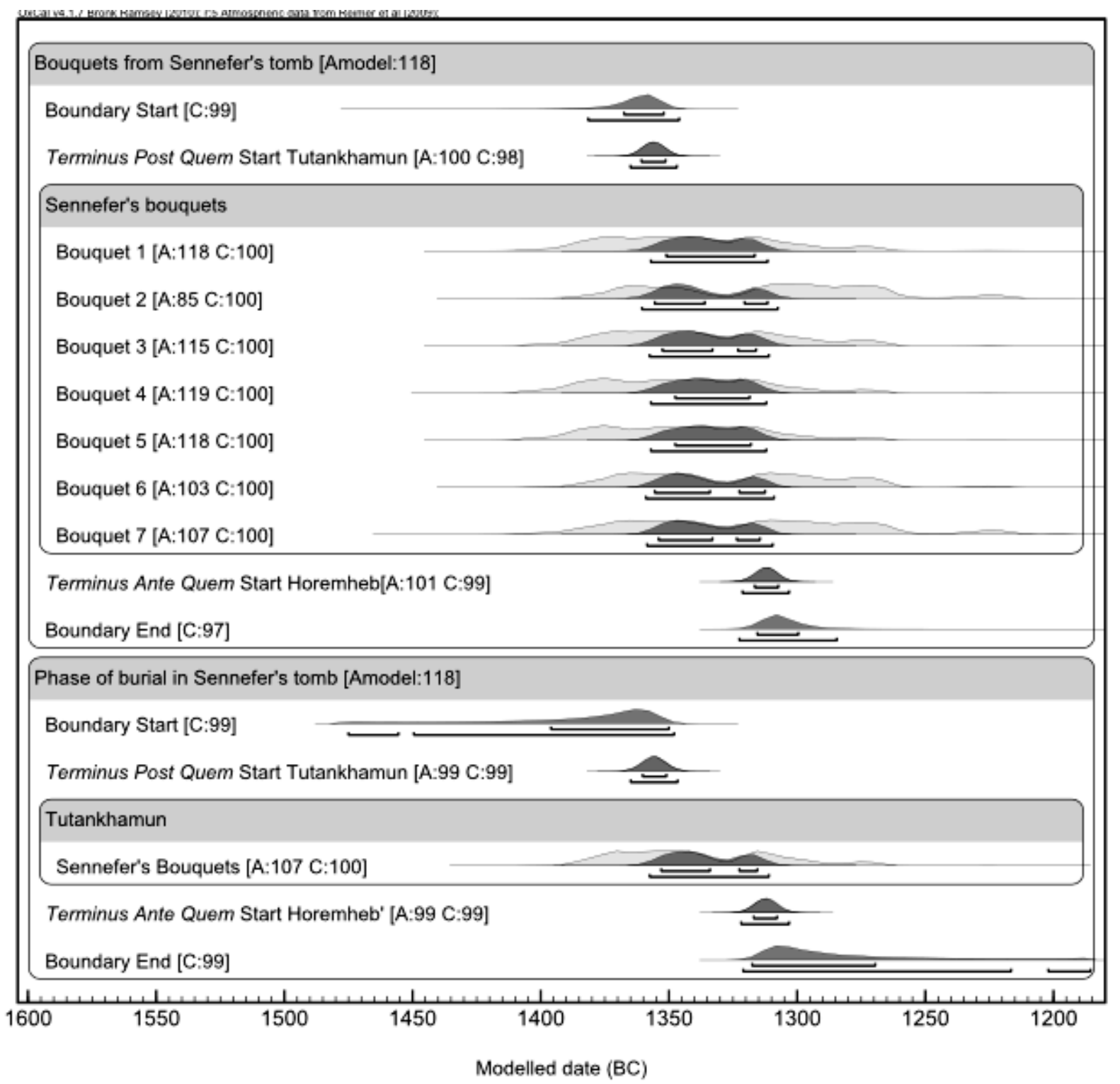

Figure 5: Modelled age for each bouquet from Sennefer's tomb (upper). The seven bouquets combined age stands for the event "one phase of burial in the Sennefer's tomb", which occurred between 1358 and 1312 calBC (2б). Termini Post and Ante Quos are deduced from Sothic method. A posteriori laws are in dark, likelihood in grey. 


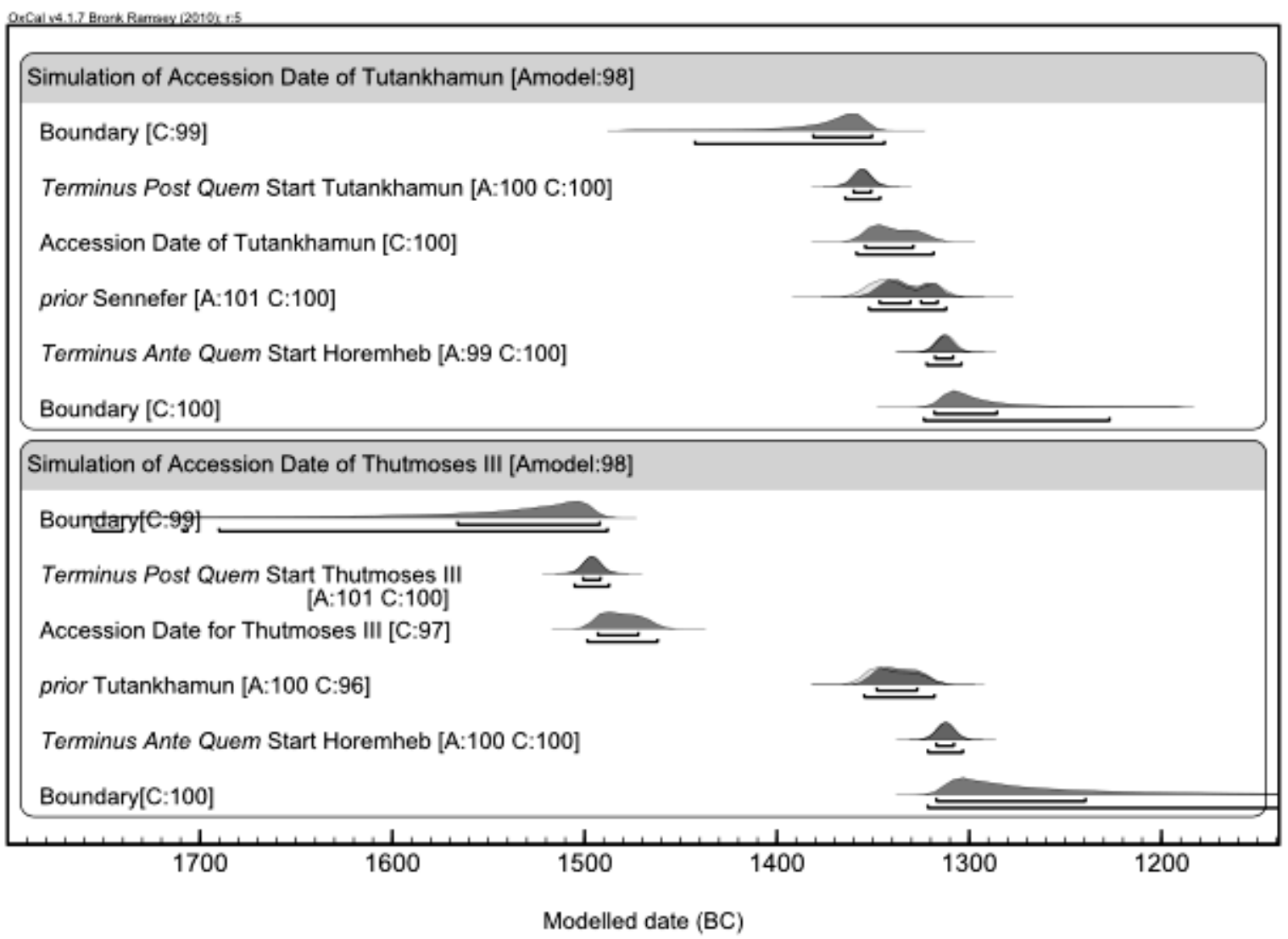

Figure 6: Simulations of Tutankhamun (upper) and Thutmoses III (down) Accession Dates, from the Sennefer

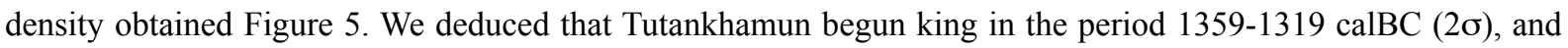
Thutmoses III between 1499 and 1463 calBC $(2 \sigma)$. 


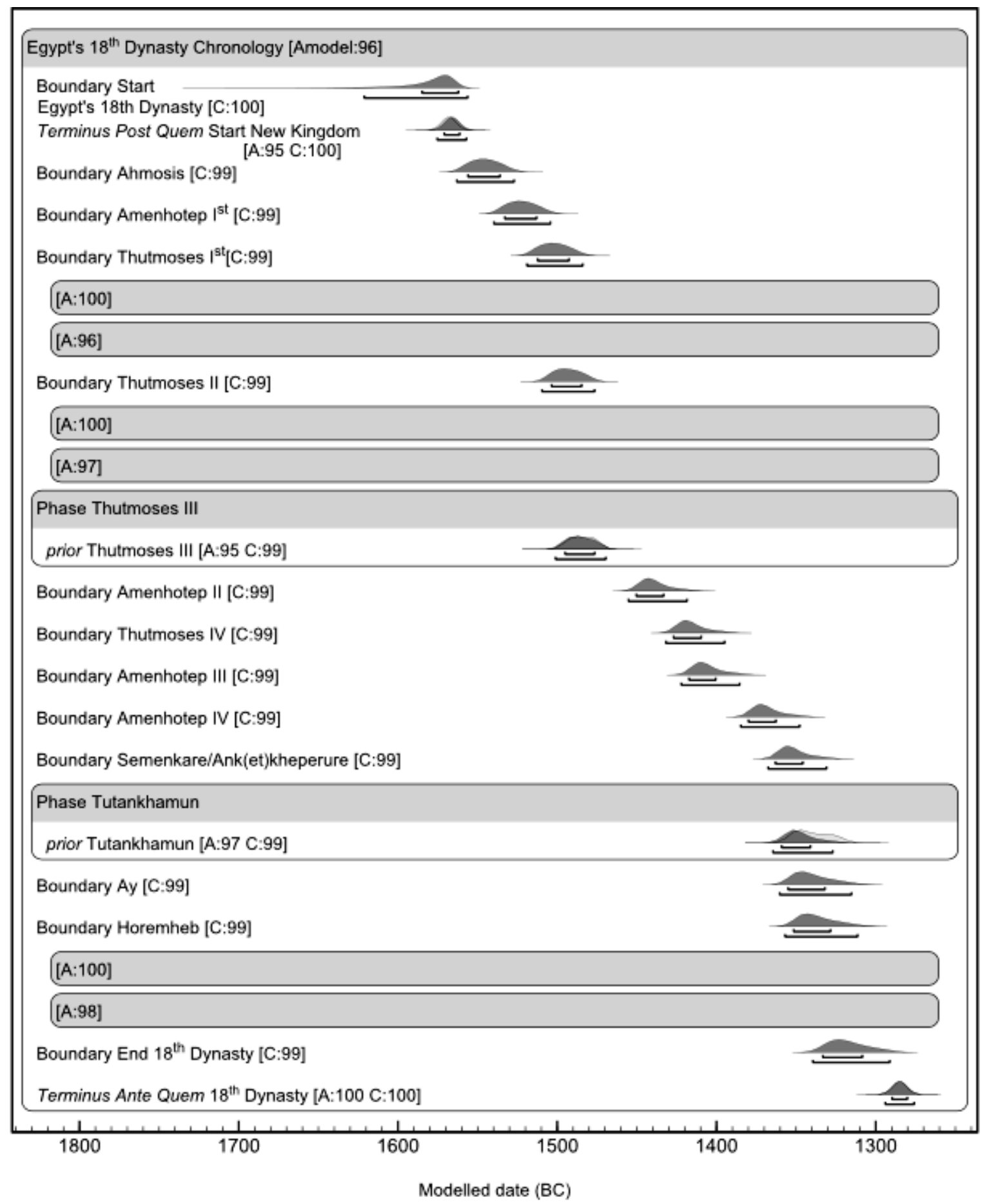

Figure 7: Simulations of kings Accession dates for Egypt's $18^{\text {th }}$ Dynasty. Deduced intervals are about 32 (Thutmoses III) to 45 (Horemheb) with 95\% probability. 


\begin{tabular}{|c|c|c|c|c|c|c|c|}
\hline Sample No. & DAE* No. & Type & mg C & $\delta^{13} \mathbf{C}$ & \multicolumn{3}{|c|}{ Radiocarbon age (BP) } \\
\hline SacA 15966 & \multirow{6}{*}{$\begin{array}{c}\text { E } 14000 \\
\text { Bouquet } 1\end{array}$} & \multirow{2}{*}{ halfa grass } & 0.70 & -28.4 & 3101 & \pm & 34 \\
\hline SacA 18758 & & & 0.22 & -26.3 & 3128 & \pm & 26 \\
\hline SacA 15967 & & \multirow{2}{*}{ leaf } & 1.30 & -29.5 & 3123 & \pm & 39 \\
\hline SacA 18759 & & & 0.22 & -29.1 & 3089 & \pm & 26 \\
\hline SacA 15968 & & \multirow{2}{*}{ reed } & 0.48 & -25.8 & 3047 & \pm & 36 \\
\hline SacA 18760 & & & 0.25 & -25.2 & 3042 & \pm & 29 \\
\hline SacA 15969 & \multirow{8}{*}{$\begin{array}{c}\text { E } 14000 \\
\text { Bouquet } 2\end{array}$} & \multirow{2}{*}{ leaf } & 1.20 & -30.3 & 3031 & \pm & 36 \\
\hline SacA 18761 & & & 0.38 & -34.1 & 2990 & \pm & 44 \\
\hline SacA 15970 & & \multirow{2}{*}{ twig } & 0.79 & -30.4 & 3024 & \pm & 37 \\
\hline SacA 18762 & & & 0.22 & -32.1 & 3085 & \pm & 26 \\
\hline SacA 15971 & & \multirow{2}{*}{ halfa grass or reed } & 0.77 & -26.6 & 3079 & \pm & 35 \\
\hline SacA 18763 & & & 0.22 & -25.5 & 3170 & \pm & 26 \\
\hline SacA 15972 & & \multirow{2}{*}{ reed } & 1.20 & -30.0 & 166 & \pm & 30 \\
\hline SacA 18764 & & & 0.71 & -30.6 & -94 & \pm & 43 \\
\hline SacA 15973 & \multirow{6}{*}{$\begin{array}{c}\text { E } 14000 \\
\text { Bouquet } 3\end{array}$} & \multirow{2}{*}{ twig } & 1.10 & -28.6 & 3029 & \pm & 35 \\
\hline SacA 18765 & & & 0.22 & -27.1 & 3060 & \pm & 26 \\
\hline SacA 15974 & & \multirow{2}{*}{ leaf } & 1.40 & -30.8 & 3040 & \pm & 36 \\
\hline SacA 18766 & & & 0.23 & -32.4 & 2990 & \pm & 26 \\
\hline SacA 15975 & & \multirow{2}{*}{ reed } & 1.00 & -25.4 & 3088 & \pm & 33 \\
\hline SacA 18767 & & & 0.21 & -22.4 & 3113 & \pm & 25 \\
\hline SacA 15976 & \multirow{7}{*}{$\begin{array}{c}\text { E } 14000 \\
\text { Bouquet } 4\end{array}$} & \multirow{2}{*}{ MO } & 0.91 & -28.3 & 3015 & \pm & 34 \\
\hline SacA 18768 & & & 0.86 & -25.7 & 3137 & \pm & 26 \\
\hline SacA 15977 & & \multirow{2}{*}{ reed } & 0.83 & -25.2 & 3044 & \pm & 37 \\
\hline SacA 18769 & & & 0.79 & -24.6 & 3131 & \pm & 28 \\
\hline SacA 15978 & & reed & 0.31 & -25.5 & 2999 & \pm & 33 \\
\hline SacA 15979 & & \multirow{2}{*}{ leaf } & 0.90 & -30.2 & 3046 & \pm & 36 \\
\hline SacA 18770 & & & 0.60 & -30.5 & 3120 & \pm & 27 \\
\hline SacA 15980 & \multirow{10}{*}{$\begin{array}{c}\text { E } 14000 \\
\text { Bouquet } 5\end{array}$} & \multirow{2}{*}{ OM } & 1.10 & -26.9 & 3100 & \pm & 41 \\
\hline SacA 18771 & & & 0.86 & -25.9 & 3170 & \pm & 25 \\
\hline SacA 15981 & & \multirow{2}{*}{ reed } & 0.75 & -27.6 & 3076 & \pm & 35 \\
\hline SacA 18772 & & & 1.20 & $-27,0$ & 2924 & \pm & 27 \\
\hline SacA 15982 & & $\log f$ & 1.50 & -30.3 & 3135 & \pm & 39 \\
\hline SacA 18773 & & leai & 0.50 & -33.2 & 3049 & \pm & 26 \\
\hline SacA 15983 & & twio & 0.60 & -26.9 & 1587 & \pm & 34 \\
\hline SacA 18774 & & twig & 0.23 & -27.6 & 1178 & \pm & 29 \\
\hline SacA 15984 & & twio & 1.22 & -27.9 & 3044 & \pm & 36 \\
\hline SacA 18775 & & tWig & 0.86 & -29.8 & 3116 & \pm & 29 \\
\hline SacA 15985 & & OM & 1.09 & -30.4 & 3004 & \pm & 34 \\
\hline SacA 18776 & & OMI & 0.24 & -25.9 & 2984 & \pm & 28 \\
\hline SacA 15986 & & OM & 1.19 & -28.3 & 3104 & \pm & 34 \\
\hline SacA 15987 & $\begin{array}{l}\text { E } 14000 \\
\text { Bouguet } 6\end{array}$ & & 1.05 & -28.4 & 3055 & \pm & 33 \\
\hline SacA 18778 & & wood? & 0.24 & -27.3 & 3089 & \pm & 28 \\
\hline SacA 15988 & & $100 f$ & 1.35 & -29.2 & 3041 & \pm & 34 \\
\hline SacA 18779 & & leat & 0.33 & -36.9 & 2864 & \pm & 38 \\
\hline SacA 15989 & & & 1.28 & -27.9 & 3086 & \pm & 35 \\
\hline SacA 18780 & $\begin{array}{l}\text { E } 14000 \\
\text { Boupt } 7\end{array}$ & twig & 0.23 & -25.3 & 3190 & \pm & 28 \\
\hline SacA 15990 & & leaf & 1.47 & -27.7 & 3036 & \pm & 37 \\
\hline
\end{tabular}

TAB 1: Results of 47 samples from Sennefer Tomb undergoing AMS radiocarbon dating. Outliers are identified in grey $\left({ }^{*}\right.$ Département des Antiquités égyptiennes, Musée du Louvre). 


\begin{tabular}{|c|c|c|c|c|c|c|c|}
\hline Sample No. & DAE* No. & Type & mg C & $\delta^{13} \mathbf{C}$ & Radioca & age & \\
\hline SacA 11129 & \multirow{8}{*}{ E 14477} & Palm frond & 0.50 & -28.6 & 3164 & \pm & 28 \\
\hline SacA 11130 & & Palm frond & 0.60 & -26.8 & 3202 & \pm & 23 \\
\hline SacA 11131 & & Textile & 0.70 & -22.7 & 3231 & \pm & 22 \\
\hline SacA 11132 & & Date & 0.90 & -16.8 & 3171 & \pm & 36 \\
\hline OxA 19448 & & Palm frond & 2.10 & -27.1 & 3245 & \pm & 30 \\
\hline OxA 19449 & & Palm frond & 1.80 & -26.1 & 3275 & \pm & 31 \\
\hline OxA 19450 & & Textile & 2.14 & -23.7 & 3291 & \pm & 31 \\
\hline OxA 19451 & & Textile & 1.83 & -23.9 & 3237 & \pm & 30 \\
\hline SacA 11134 & \multirow{4}{*}{ E 14489} & Palm frond & 0.77 & -28 & 3226 & \pm & 22 \\
\hline SacA 11135 & & Textile & 1.01 & -27.5 & 3097 & \pm & 21 \\
\hline SacA 16397 & & Halfa grass & 0.39 & -10.1 & 3202 & \pm & 25 \\
\hline SacA 16398 & & Palm frond & 0.44 & $-29,6$ & 3232 & \pm & 26 \\
\hline SacA 11137 & \multirow{2}{*}{ Е 16390} & Palm frond & 0.84 & -29.3 & 3170 & \pm & 25 \\
\hline SacA 11138 & & Halfa grass & 0.85 & -11.3 & 3260 & \pm & 30 \\
\hline SacA 11139 & \multirow{3}{*}{ E 16394} & Halfa grass & 0.80 & -10.8 & 3224 & \pm & 24 \\
\hline SacA 16399 & & Halfa grass & 0.63 & -10.7 & 3188 & \pm & 23 \\
\hline OxA 19452 & & Halfa grass & 1.60 & -10.7 & 3227 & \pm & 30 \\
\hline SacA 11140 & \multirow{3}{*}{ E 16396} & Halfa grass & 0.95 & -13.2 & 3250 & \pm & 25 \\
\hline SacA 11141 & & Palm frond & 1.00 & -25.6 & 170 & \pm & 25 \\
\hline SacA 16400 & & Halfa grass & 0.52 & -12.5 & 3191 & \pm & 24 \\
\hline SacA 11143 & \multirow{3}{*}{ E 16397} & Halfa grass & 0.80 & -26.0 & 165 & \pm & 21 \\
\hline SacA 16401 & & Halfa grass & 0.38 & -13.4 & 3271 & \pm & 29 \\
\hline OxA 19146 & & Halfa grass & 1.60 & -10.7 & 127 & \pm & 24 \\
\hline SacA 11144 & \multirow{2}{*}{ E 16391} & Halfa grass & 0.08 & -10.6 & 3377 & \pm & 53 \\
\hline SacA 11145 & & Palm frond & 0.46 & -26.2 & 3196 & \pm & 22 \\
\hline SacA 11148 & \multirow{6}{*}{ E 14488} & Halfa grass & 0.25 & -17.6 & 3089 & \pm & 31 \\
\hline SacA 11149 & & Palm frond & 0.80 & -19.4 & 3280 & \pm & 26 \\
\hline SacA 16405 & & Halfa grass & 0.86 & -10.4 & 3219 & \pm & 25 \\
\hline SacA 16406 & & Plant & 0.42 & -15.8 & 3163 & \pm & 28 \\
\hline OxA 19453 & & Halfa grass & 1.70 & -12 & 3264 & \pm & 29 \\
\hline OxA 19480 & & Palm frond & 1.90 & -24.4 & 3251 & \pm & 26 \\
\hline SacA 11150 & \multirow{5}{*}{ E 14491} & Halfa grass & 0.30 & -8.2 & 3185 & \pm & 28 \\
\hline SacA 11151 & & Halfa grass & 0.90 & -17.3 & 260 & \pm & 24 \\
\hline SacA 16411 & & Halfa grass & 0.44 & -13.4 & 3193 & \pm & 27 \\
\hline OxA X-2287 & & Halfa grass & 0.40 & -8.7 & 3283 & \pm & 33 \\
\hline OxA 19149 & & Halfa grass & 0.90 & -22.1 & 165 & \pm & 23 \\
\hline SacA 11152 & \multirow{4}{*}{ E 14480} & Halfa grass & 0.60 & -10.2 & 3178 & \pm & 25 \\
\hline SacA 11153 & & Palm frond & 0.50 & -28.1 & 3261 & \pm & 28 \\
\hline OxA 19481 & & Halfa grass & 1.70 & -10.1 & 3233 & \pm & 25 \\
\hline OxA 19150 & & Palm frond & 1.00 & -26.3 & 3153 & \pm & 27 \\
\hline SacA 11154 & \multirow{3}{*}{ E 14487} & Palm frond & 1.00 & -23.9 & 3304 & \pm & 25 \\
\hline SacA 11155 & & Halfa grass & 0.60 & -12.4 & 3041 & \pm & 25 \\
\hline OxA 19482 & & Palm frond & 1.50 & -25.3 & 3277 & \pm & 26 \\
\hline SacA 11156 & \multirow{9}{*}{ E 14479} & Halfa grass & 0.70 & -11.8 & 3198 & \pm & 25 \\
\hline SacA 11158 & & Textile & 0.80 & -25.2 & 3284 & \pm & 22 \\
\hline SacA 11159 & & Palm frond & 0.80 & -24.8 & 3305 & \pm & 23 \\
\hline SacA 16409 & & Halfa grass & 0.69 & -10.3 & 3259 & \pm & 24 \\
\hline SacA 16410 & & Halfa grass & 0.59 & -10.5 & 3214 & \pm & 24 \\
\hline OxA 19151 & & Halfa grass & 1.20 & -10.3 & 3107 & \pm & 27 \\
\hline OxA 19581 & & Halfa grass & 2.10 & -9.9 & 3258 & \pm & 26 \\
\hline OxA 19483 & & Textile & 1.70 & -24.6 & 3226 & \pm & 26 \\
\hline OxA 19484 & & Palm frond & 2,00 & -25.2 & 3257 & \pm & 26 \\
\hline SacA 11160 & & Halfa grass & 0.70 & -10.7 & 3200 & \pm & 22 \\
\hline
\end{tabular}




\begin{tabular}{|c|c|c|c|c|c|c|c|}
\hline SacA 11161 & \multirow{4}{*}{ E 14483} & Palm frond & 0.50 & -29 & 3207 & \pm & 31 \\
\hline OxA 19485 & & Halfa grass & 1.90 & -10.6 & 3262 & \pm & 25 \\
\hline OxA 19152 & & Palm frond & 0.80 & -24.4 & 3249 & \pm & 28 \\
\hline OxA 19486 & & Cyperus Papyrus & 2.10 & -24.3 & 182 & \pm & 22 \\
\hline SacA 11162 & \multirow{4}{*}{ E 16401} & Cyperus Papyrus & 0.60 & -26.8 & 178 & \pm & 21 \\
\hline SacA 11163 & & Palm frond & 0.70 & -25.1 & 3283 & \pm & 22 \\
\hline SacA 11164 & & Halfa grass & 0.60 & -10.5 & 3161 & \pm & 22 \\
\hline SacA 16407 & & Halfa grass & 0.40 & -13.3 & 3234 & \pm & 31 \\
\hline SacA 11165 & \multirow{2}{*}{ E 16393} & Halfa grass & 0.18 & -15.4 & 3197 & \pm & 28 \\
\hline SacA 11166 & & Palm frond & 0.55 & -25.2 & 3155 & \pm & 25 \\
\hline SacA 11167 & \multirow{7}{*}{ E 14617} & Grape & 0.72 & -27.8 & 3161 & \pm & 25 \\
\hline SacA 11168 & & Plant remains & 0.20 & 9.5 & 3756 & \pm & 61 \\
\hline SacA 11169 & & Halfa grass & 1.00 & -21.8 & 112 & \pm & 18 \\
\hline SacA 11170 & & Textile & 1.00 & -24.2 & 3285 & \pm & 22 \\
\hline OxA X-2287 & & Plant remains & 0.40 & -22.4 & 3333 & \pm & 33 \\
\hline OxA 19153 & & Halfa grass & 1.10 & -22.1 & 110 & \pm & 23 \\
\hline OxA 19154 & & Textile & 1.10 & -24.5 & 3209 & \pm & 28 \\
\hline SacA 11171 & \multirow{2}{*}{ E 16425} & Grape & 1.30 & -27.8 & 3241 & \pm & 26 \\
\hline SacA 11172 & & Textile & 0.42 & -25.8 & 3192 & \pm & 23 \\
\hline SacA 16402 & \multirow{5}{*}{ E 14665} & Palm frond & 0.72 & -25.8 & 3234 & \pm & 25 \\
\hline SacA 16403 & & Palm frond & 0.53 & -28.7 & 3200 & \pm & 23 \\
\hline SacA 16404 & & Palm frond & 0.50 & -28.3 & 3232 & \pm & 25 \\
\hline OxA 19147 & & Halfa grass & 0.50 & -10.6 & 3261 & \pm & 32 \\
\hline OxA 19148 & & Palm frond & 0.90 & -23.4 & 3186 & \pm & 28 \\
\hline SacA 16408 & E 14487 & Halfa grass & 0.45 & -12.9 & 3243 & \pm & 25 \\
\hline
\end{tabular}

TAB 2: Results of 78 basketries samples from the eastern cemetery of Deir el-Medineh, undergoing AMS radiocarbon dating at LMC14 (SacA-53) and ORAU (OxA and OxA X (small carbon mass sample)-25) laboratories. ( ${ }^{*}$ Département des Antiquités égyptiennes, Musée du Louvre). Outliers are identified in grey. 


\begin{tabular}{|c|c|c|c|c|c|}
\hline \multirow[b]{2}{*}{$\begin{array}{l}\text { King of } 18^{\text {th }} \\
\text { Dynasty }\end{array}$} & \multirow{2}{*}{$\begin{array}{l}\text { Length of reigns } \\
\text { Principally from } \\
\text { (Hornung et al, } \\
\text { 2006) }\end{array}$} & \multirow{2}{*}{$\begin{array}{l}\text { Distribution Law on } \\
\text { length of reign }\end{array}$} & \multicolumn{3}{|c|}{ Modelled Interval for accession date } \\
\hline & & & $\begin{array}{c}68 \% \\
\text { (calBC) }\end{array}$ & $\begin{array}{c}95 \% \\
\text { (calBC) }\end{array}$ & Convergence \\
\hline Ahmosis & $21-25$ & $\mathrm{U}(21,25)$ & $1557-1537$ & $1564-1528$ & 99 \\
\hline Amenhotep Ist $^{\text {st }}$ & $20-21$ & $\mathrm{U}(20,21)$ & $1533-1514$ & $1540-1505$ & 99 \\
\hline Thutmoses Ist & $3-13$ & After(3)\&Before $(13+\mathrm{T}(5))$ & $1513-1493$ & $1520-1485$ & 99 \\
\hline Thutmoses II & $2-13$ & After(2)\&Before $(13+\mathrm{T}(5))$ & $1504-1485$ & $1510-1477$ & 99 \\
\hline Thutmoses III & 53 & \begin{tabular}{|c|} 
Prior \\
(Simulated age/Lunar Dates/ \\
basketries)
\end{tabular} & $1496-1477$ & $1502-1470$ & 99 \\
\hline Amenhotep II & $22-25$ & $\mathrm{U}(22,25)$ & $1451-1434$ & $1456-1419$ & 99 \\
\hline Thutmoses IV & $9-10$ & $\mathrm{U}(9,10)$ & $1427-1410$ & $1432-1395$ & 99 \\
\hline Amenhotep III & $37-38$ & $\mathrm{U}(37,38)$ & $1418-1401$ & $1423-1386$ & 99 \\
\hline Amenhotep IV & $16-18$ & $\mathrm{U}(16,18)$ & $1380-1363$ & $1385-1348$ & 99 \\
\hline $\begin{array}{c}\text { Semenkhare/ } \\
\text { Ank(et)kheperure }\end{array}$ & $3-5$ & $\mathrm{U}(3,5)$ & $1363-1346$ & $1368-1331$ & 99 \\
\hline Tutankhamun & $9-10$ & Prior & $1360-1342$ & $1365-1328$ & 99 \\
\hline Ay & $3-4$ & $\mathrm{U}(3,4)$ & $1356-1332$ & $1361-1316$ & 99 \\
\hline Horemheb & $13-27$ & After(13)\&Before $(27+\mathrm{T}(5))$ & $1352-1329$ & $1357-1312$ & 99 \\
\hline $\begin{array}{c}\text { End of } 18^{\text {th }} \\
\text { dynasty }\end{array}$ & - & - & 1334-1309 & $1340-1292$ & 99 \\
\hline
\end{tabular}

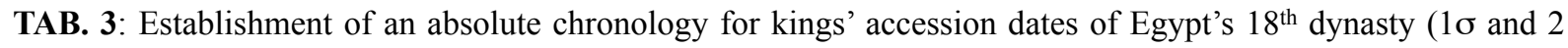
$\sigma)$. 